\title{
The role of PPAR in myocardial response to ischemia in normal and diseased heart
}

\author{
Tana Ravingerova ${ }^{1}$, Adriana Adameova $^{2}$, Slavka Carnicka ${ }^{1}$, Martina Nemcekova ${ }^{1}$, Tara Kelly ${ }^{3}$, \\ Jana Matejikova ${ }^{1}$, Eleftheria Galatou ${ }^{3}$, Eleftheria Barlaka ${ }^{3}$ and Antigone Lazou ${ }^{3}$ \\ ${ }^{1}$ Institute for Heart Research, Slovak Academy of Sciences, Centre of Excellence NOREG SAS, Bratislava, Slovak Republic \\ ${ }^{2}$ Department of Pharmacology and Toxicology, Faculty of Pharmacy, Comenius University, Bratislava, Slovak Republic \\ ${ }^{3}$ School of Biology, Aristotle University of Thessaloniki, Thessaloniki, Greece
}

\begin{abstract}
Peroxisome proliferator-activated receptors (PPAR), ligand-activated transcription factors, belong to the nuclear hormone receptor superfamily regulating expression of genes involved in different aspects of lipid metabolism, inflammation and cardiac energy production. Activation of PPAR- $\alpha$ isoform by its natural ligands, fatty acids (FA) and eicosanoids, promotes mitochondrial FA oxidation as the primary ATP-generating pathway. On the other hand, PPAR- $\gamma$ regulates lipid anabolism or storage, while, until recently, the function of PPAR- $\beta / \delta$ has been less explored. Under conditions associated with acute or chronic oxygen deprivation, PPAR- $\alpha$ modulates expression of genes that determine substrate switch (FA vs. glucose) aimed at maintenance of basic cardiac function. Although PPAR- $\alpha$ and PPAR- $\gamma$ synthetic agonists, hypolipidemic and antidiabetic drugs, have been reported to protect the heart against ischemia/ reperfusion injury, it is still a matter of debate whether PPAR activation plays a beneficial or detrimental role in myocardial response to ischemia, in particular, in pathological conditions. This article reviews some findings demonstrating the impact of PPAR activation on cardiac resistance to ischemia in normal and pathologically altered heart. Specifically, it addresses the issue of susceptibility to ischemia in the diabetic myocardium, with particular regards to the role of PPAR. Finally, involvement of PPAR in the mechanisms of lipid-independent cardioprotective effects of some hypolipidemic drugs is also discussed.
\end{abstract}

Key words: Peroxisome proliferator-activated receptors - Myocardial ischemia - Cardioprotection - Hypolipidemic drugs - HMG-CoA reductase inhibitors - Pleiotropic effects

\begin{abstract}
Abbreviations: CPT1, carnitine palmitoyltransferase; ERK, extracellular signal regulated kinase; FA, fatty acids; GLUT4, glucose transporter; I/R, ischemia/reperfusion; ISGF-RE, interferon stimulated gene factor response element; MAPK, mitogen-activated protein kinases; MCAD, medium-chain acyl-CoA dehydrogenase; NF- $\kappa \mathrm{B}-\mathrm{RE}, \mathrm{NF}-\kappa \mathrm{B}$ response element; PDK4, pyruvate dehydrogenase; PPAR, peroxisome proliferator-activated receptors; PPRE, PPAR response element; RXR, retinoid $\mathrm{X}$ receptor; STAT, signal transducer and activator of transcription; TRE, TPA (12-O-tetradecanoylphorbol-13-acetate) response element.
\end{abstract}

\section{Introduction}

Peroxisome proliferator-activated receptors (PPAR) are ligand-activated transcription factors that belong to the nu-

Correspondence to: Tana Ravingerova, Institute for Heart Research, Slovak Academy of Sciences, P.O.Box 104, Dúbravská cesta 9, 84005 Bratislava, Slovak Republic

E-mail: usrdravi@savba.sk clear hormone receptor superfamily regulating expression of genes involved in different aspects of lipid metabolism (Desvergne and Wahli 1999; Kliewer et al. 2001), energy production (Barger and Kelly 2000) and inflammation (Michalik and Wahli 2006). All three isoforms of PPAR detected so far PPAR- $\alpha$, PPAR- $\beta / \delta$ and PPAR- $\gamma$, encoded by separate genes, are expressed in many species including rodents (Kliewer et al. 1994) and humans (Greene et al. 1995). They differ in their tissue distribution, ligand specificity and cofactor interac- 
tions (Braissant et al. 1996; Escher at al. 2001). Therefore, PPAR isoforms regulate different sets of genes and there are different biological consequences of their stimulation. PPAR- $\alpha$ has been recognized as the central regulator of mitochondrial fatty acids (FA) catabolism, whereas PPAR- $\gamma$ is believed to regulate lipid anabolism or storage. Until recently, the function of PPAR- $\beta / \delta$ was relatively less explored. However, several lines of evidence suggest that all three isoforms modulate cardiac energy metabolism (Desvergne and Wahli 1999; Kliewer et al. 2001). Nevertheless, it is still a matter of debate whether PPAR activation plays a beneficial or detrimental role in the setting of ischemia/reperfusion (I/R), in particular in pathologically altered myocardium. Conflicting findings have documented both, negative impact of PPAR- $\alpha$ up-regulation on myocardial functional recovery upon I/R (Panagia et al. 2005; Sambandam et al. 2006), in particular during early reperfusion (Kantor et al. 2000), and beneficial effects of PPAR- $\alpha$ and PPAR- $\gamma$ agonists on I/R damage (Tabernero et al. 2002; Wayman et al. 2002; Yue et al. 2003; Yeh et al. 2006). This contradiction is apparently related to the fact that PPAR activation may improve myocardial function via metabolic or other, metabolic-independent, actions.

\section{Tissue distribution and function of PPAR}

Main tissue distribution and physiological effects of PPAR isoforms are illustrated in Table 1 . Two of the three PPAR isoforms, PPAR- $\alpha$ and PPAR- $\beta / \delta$ are abundantly expressed in tissues with high level of FA oxidation (FAO) including heart, liver, kidney, skeletal muscle and pancreas (Braissant et al. 1996; Gilde et al. 2003). PPAR- $\gamma$ (and its splice variants) is mainly associated with adipose tissue and macrophages, with a low level of more ubiquitous expression in liver, heart, skeletal muscle and bone marrow (Escher et al. 2001). PPAR- $\beta / \delta$ is abundantly and ubiquitously expressed at much higher levels than PPAR- $\gamma$ and PPAR- $\alpha$ (Kliewer et al. 1994). It is important to note that tissue expression of all three PPAR isotypes may vary under different physiological and/or pathological conditions.

Heart tissue normally utilizes FA as the major energy source, and PPAR- $\alpha$ regulates genes encoding enzymes of FA transport/uptake and utilization via $\beta$-oxidation in mitochondria (Finck 2007). Activation of PPAR- $\alpha$ by its natural ligands (long-chain FA, eicosanoids) promotes mitochondrial FAO as the primary ATP-generating pathway in the normal adult myocardium (Barger and Kelly 2000; Finck 2007). Moreover, under physiological and pathological conditions associated with acute or chronic oxygen deprivation, PPAR- $\alpha$ modulates expression of genes that determine myocardial substrate selection (FA versus carbohydrates) in order to maintain adequate production of energy and preserve basic cardiac function (Huss and Kelly 2004). In ad- dition, involvement of PPAR in anti-inflammatory response in different tissues has been also recognized (Delerive et al. 2001; Smeets et al. 2007).

\section{Mechanisms of action of PPAR}

\section{Natural and synthetic PPAR ligands}

Upon binding to PPAR, different ligands can induce stimulatory or inhibitory responses depending on the nature of the specific target gene and its cellular location. Both natural and synthetic compounds have been recognized as PPAR ligands. Although many FA are capable of activating all three PPAR isoforms, some preference for specific FA by each PPAR has been demonstrated (reviewed by Collino et al. 2008). The long-chain polyunsaturated FA and their oxidized derivatives, especially eicosanoids such as 8-S-hydroxyeicosatetraenoic acid (8-S-HETE), leukotriene B4 (LTB4), and arachidonate monooxygenase metabolite epoxyeicosatrienoic acids have been shown to potently activate PPAR- $\alpha$ with high affinity (Feige et al. 2006). PPAR- $\gamma$ can be activated by several prostanoids, such as 15-deoxy-12,14-prostaglandin J2 (15d-PGJ2) and 12- and 15-hydroxy-eicosatetraenoic acid (12- and 15-HETE), which are derivatives of arachidonic acid synthesized through the lipoxygenase pathway (Theocharis et al. 2004). Prostaglandin 15d-PGJ2 is not only the most potent natural ligand for PPAR- $\gamma$ identified to date, but also by far the most commonly used naturally occurring PPAR- $\gamma$ agonist (Forman et al. 1997). In addition to PPAR- $\gamma$ naturally occurring agonists produced by human body, flavonoids psibaptigenin and hesperidin found in plants were identified as strong PPAR- $\gamma$ agonists (Salam et al. 2008).

Several synthetic agonists of PPAR- $\alpha$ and PPAR- $\gamma$ are known as marketed drugs used in the treatment of hypertrigliceridemia and diabetes mellitus, respectively (Ballantyne et al. 2003; Tenenbaum et al. 2004). Hypolipidemic drugs fibrates (e.g. fenofibrate, clofibrate) are well-known synthetic ligands for PPAR-a (Theocharis et al. 2004). Fibrates activate PPAR- $\alpha$ leading to increased expression of lipid metabolizing enzymes that effectively lower serum lipid levels, in particular triacylglycerides, in humans.

The most widely used synthetic PPAR- $\gamma$ agonists belong to the thiazolidinedione (TZD) or glitazone class of antidiabetic drugs used in the treatment of type- 2 diabetes. The two available TZDs, rosiglitazone and pioglitazone, are currently used alone or in combination with other oral anti-diabetic agents (Theocharis et al. 2004). These drugs are known as insulin sensitizers stimulating the tissue uptake of glucose in the diabetics (Sidell et al. 2002), however, their action extends far beyond their hypoglycemic activity (Khandoudi et al. 2002; Shiomi et al. 2002; Lee et al. 2003). Table 2 summarizes currently known PPAR modulators, as 
Table 1. Tissue distribution and physiological effects of PPAR isoforms

\begin{tabular}{lll}
\hline PPAR isoform & Tissue distribution & Effects \\
\hline PPAR- $\alpha$ & Liver, skeletal muscle, heart, kidney, adipose tissue & FA metabolism, cell cycle, control of inflammation and apoptosis \\
PPAR- $\beta / \delta$ & Ubiquitously & FA metabolism, wound healing, control of inflammation \\
PPAR- $\gamma 1$ & All tissues including heart, muscle, kidney & $\begin{array}{l}\text { Adipogenesis, lipid storage, control of inflammation and apopto- } \\
\text { sis, increased insulin sensitivity and glucose disposal }\end{array}$ \\
PPAR- -2 & Adipose tissue & \\
PPAR- $\gamma 3$ & Macrophages & \\
\hline
\end{tabular}

well as clinically important PPAR- $\alpha$ and PPAR- $\gamma$ agonists, fibrates and glitazones, respectively.

\section{Transcriptional transactivation}

Upon activation by endogenous or synthetic ligands, PPAR form obligate heterodimers with the 9-cis retinoic acid receptors (retinoid X receptor, RXR). The resulting complex undergoes a conformational change which allows binding of the heterodimer to a DNA sequence in the promoter region of target genes known as the PPAR response element (PPRE) followed by the induction of gene transcription (Kliewer et al. 1992; Forman et al. 1997) and synthesis of the respective gene products. When both PPAR and RXR are activated simultaneously, it results in significant synergistic enhancement of gene transcription (Kliewer et al. 1992). The search for PPAR target genes with identified PPREs has led to the identification of numerous genes involved in lipid metabolism, oxidative stress and the inflammatory response (Desvergne and Wahli 1999; Delerive et al. 2001; Tan et al. 2005; Finck 2007), as well as genes responsible for insulin signaling and glucose metabolism (Grossman and Lessem 1997; Oshida et al. 1999).

\section{Transcriptional transrepression}

In addition to PPAR transactivation, stimulation of PPAR can also negatively regulate gene expression in a liganddependent manner by inhibiting the activities of other transcription factors, such as activated protein-1 (AP-1), nuclear factor-kappaB (NF- $\kappa \mathrm{B})$, nuclear factor of activated T-cells (NFAT) or signal transducer and activator of transcription (STAT) via mechanism known as ligand-dependent transrepression (Abdelrahman et al. 2005). In contrast to transcriptional activation, transrepression does not involve binding of PPAR to response elements of the target genes but direct interaction with other transcription factors and co-repressors or modulation of kinase activity.

Research suggests that PPAR may exert beneficial effects by negatively regulating the expression of pro-inflammatory genes in inflammation-related diseases including myocardial ischemia/reperfusion injury (Abdelrahman et al. 2005). Several mechanisms have been suggested to account for this activity including ligand-independent repression of the transcription of target genes via binding of PPAR to response element in the absence of ligands and recruitment of the co-repressor complexes (reviewed by Collino et al. 2008).

\section{Regulation of PPAR activity}

Many proteins act as co-activators or co-repressors that regulate the ability of PPAR to either stimulate or repress gene transcription. In the unbound state, PPAR/RXR heterodimers are associated with co-repressors, which prevent gene transcription. However, once a ligand binds to the receptor, a conformational change occurs that not only facilitates co-repressor dissociation, but also the recruitment of several positive co-activators that initiates a sequence of events ultimately leading to gene transcription (Shibata et al. 1997).

Although co-activators and co-repressors appear to be the major factors responsible for regulation of PPAR activity, these receptors can also be modulated by mitogen-activated protein kinase (MAPK)-induced phosphorylation. In fact, phosphorylation by extracellular signal regulated kinases (ERK1/2) has been found to repress PPAR- $\alpha$ activity (Barger and Kelly 2000; Barger et al. 2000), while phosphorylation induced by $\mathrm{p} 38$-MAPK enhances PPAR- $\alpha$-mediated gene expression (Barger et al. 2001).

Figure 1 summarizes regulation of PPAR function in the cell, control of gene expression and PPAR-mediated effects.

\section{PPAR function and the outcome of myocardial ischemia/reperfusion injury}

Delivery of oxygen and metabolic substrates via coronary circulation is essential for normal cardiac function, and its cessation leads within minutes to irreversible cellular injury. The duration of ischemia and the extent of metabolic and structural alterations in the myocardium are the main factors that determine the progress towards cell death (by mechanisms of necrosis or apoptosis) or cell survival. Restoration of blood flow in the previously occluded coronary arteries is undoubtedly the main prerequisite of the heart rescue. However, 
Table 2. Naturally occurring and synthetic PPAR- $\alpha$ and PPAR- $\gamma$ modulators

\begin{tabular}{|c|c|c|}
\hline & PPAR- $\alpha$ modulators & PPAR- $\gamma$ modulators \\
\hline Naturally occurring agonists & $\begin{array}{l}\text { Fatty acids } \\
\text { Eicosanoids } \\
\text { Leukotriene B4 }\end{array}$ & $\begin{array}{l}\text { Fatty acids } \\
\text { Eicosanoids } \\
\text { Prostaglandin } \\
\text { Flavonoids: } \psi \text {-baptigenin, hesperidin }\end{array}$ \\
\hline Synthetic agonists & $\begin{array}{l}\text { Fibrates: fenofibrate, clofibrate, bezafibrate, } \\
\text { gemfibrozil } \\
\text { WY14643, GW7647 }\end{array}$ & $\begin{array}{l}\text { Thiazolidinediones (glitazones): rosiglitazone, } \\
\text { pioglitazone, ciglitazone }\end{array}$ \\
\hline Synthetic antagonists & MK-886 & GW9662 \\
\hline
\end{tabular}

reperfusion may have injurious components and limit the recovery of the tissue through the induction of "reperfusion injury" (Braunwald and Kloner 1985). I/R injury represents a clinically relevant problem associated with restoration of blood supply that occurs during trombolysis, percutaneous coronary intervention and coronary artery bypass graft surgery (Roberto and Prado 2002; Rodrígez-Sinovas et al. 2007). $\mathrm{I} / \mathrm{R}$ injury is a complex cascade of events, where oxidative stress and inflammatory response play the pivotal role (Turer and Hill 2010) and besides other factors involve activation of NF- $\kappa \mathrm{B}$ as one of the central processes (Hall et al. 2006), in particular in the ex vivo perfused heart (Li et al. 1999).

The role of PPARs in the pathogenesis of a variety of heart disorders including acute myocardial $\mathrm{I} / \mathrm{R}$ is a matter of controversy and still remains unclear. Gene expression of PPAR-a declines in chronically hypoxic heart resulting in a substrate switch from FA to glucose that has been considered as an adaptive response (Barger et al. 2000; Razeghi et al. 2001). In line, experimental overexpression of PPAR- $\alpha$ was found to be related to the impaired cardiac recovery after ischemia (Sambandam et al. 2006). It appears that in long-term processes, such as myocardial hypoxia and/or hypertrophy linked with limitations in oxygen supply, glucose as a fuel may be beneficial for the heart by decreasing oxygen consumption (Barger and Kelly 2000). Moreover, chronic activation of PPAR- $\alpha$ (and increased rates of FAO at the expense of glucose oxidation) may be detrimental to the heart during postischemic reperfusion possibly due to FAO-induced oxidative stress (Sambandam et al. 2006).

On the other hand, other studies indicated that targeted deletion of PPAR- $\alpha$ resulted in increased serum levels of free FA and a larger size of infarction in mice subjected to ischemic challenge (Yue et al. 2003). In acute settings of I/R, decrease of PPAR- $\alpha$ and corresponding metabolic effects were observed in a rat ex vivo model of 30-min ischemia/2$\mathrm{h}$ reperfusion (Tian et al. 2006) and in the in vivo mice. In these models, reversal of down-regulation of PPAR- $\alpha$ and its target genes responsible for the metabolic fuel shifts (decreased FAO and increased glucose oxidation) improved postischemic myocardial contractile recovery and reduced the size of infarction (Yue et al. 2003). In line, in our study in the isolated rat heart, 30-min global ischemia significantly decreased mRNA and protein levels of PPAR- $\alpha$ and their further decline observed following 2 -h reperfusion was accompanied by the development of irreversible myocardial injury (Ravingerová et al. 2009).

There is no clear consensus on whether attenuation of I/Rinduced down-regulation of PPAR- $\alpha$ and FAO is beneficial or detrimental to the heart. The discrepancy in the results may arise from the different substrate availability in the different experimental models (ischemia/reperfusion, in vivo versus in vitro protocols). Although FAO is an important source of energy production during the basic conditions, glucose uptake may be crucial during ischemia. It is believed that partial inhibition of FAO and a substrate switch from FA to glucose (Barger and Kelly 2000) improves functional recovery of the heart upon reperfusion (Fragasso et al. 2003) while overexpression of PPAR- $\alpha$ impairs postischemic cardiac recovery (Sambandam et al. 2006). Thus, pharmacological interventions that increase glucose oxidation and suppress FAO appear to be beneficial for the recovery of the myocardium previously subjected to I/R (Kantor et al. 2000; Panagia et al. 2005). In the long-term, however, this switch may become detrimental as less ATP is generated per mole of glucose oxidized, and lipid accumulation and lipotoxicity of the myocardium may develop (Barger and Kelly 2000). The controversy regarding the role of PPAR- $\alpha$ in the heart suggests that the function of this transcription factor might not be the same in different cardiac pathologies or in their different stages and that the effects other than lipid metabolism might be also involved. Figure 2 shows potential involvement of PPARs in the pathophysiological mechanisms of ischemia/reperfusion injury.

\section{PPAR and endogenous protection against ischemia/ reperfusion}

The role of PPAR in the mechanisms of endogenous protection against I/R injury is less documented, although 
Takeda et al. (2001) demonstrated that PPAR- $\gamma$ agonists activated ERK1/2 pathway of MAP-kinases in vascular smooth muscle cells through phosphatidylinositol 3-kinase (PI3K). Cascades of ERK1/2 and PI3K and its effector protein kinase B (Akt) are implicated in protective mechanisms of ischemic preconditioning and other forms of intrinsic cardioprotection (Hausenloy et al. 2005; Ravingerová et al. 2007). It has also been hypothesized that PPAR activation prior to I/R could confer preconditioning-like protection to the myocardium (Wynne et al. 2005). Indeed, increased PPAR- $\gamma$ activity resulted in significant anti-infarct protection comparable with the effect of classical ischemic preconditioning that appeared to involve both survival cascades (ERK1/2 and PI3K/Akt).

Moreover, it has been shown that PPAR- $\gamma$ participates in a delayed effect of preconditioning with endotoxin (lipopolysaccharide, LPS) on myocardial and renal I/R injury in rats (Collino et al. 2005; Sivarajah et al. 2005). In addition, pretreatment of rabbits with anaesthetic desflurane has been reported to induce overproduction of endogenous PPAR- $\gamma$ agonists, such as 15d-PGJ2 and others, resulting in a delayed infarct size-limiting protection (Lotz et al. 2011a). Recently, the involvement of both, PPAR- $\alpha$ and PPAR- $\gamma$ isoforms in the mechanisms of "remote" (renal ischemia-induced)

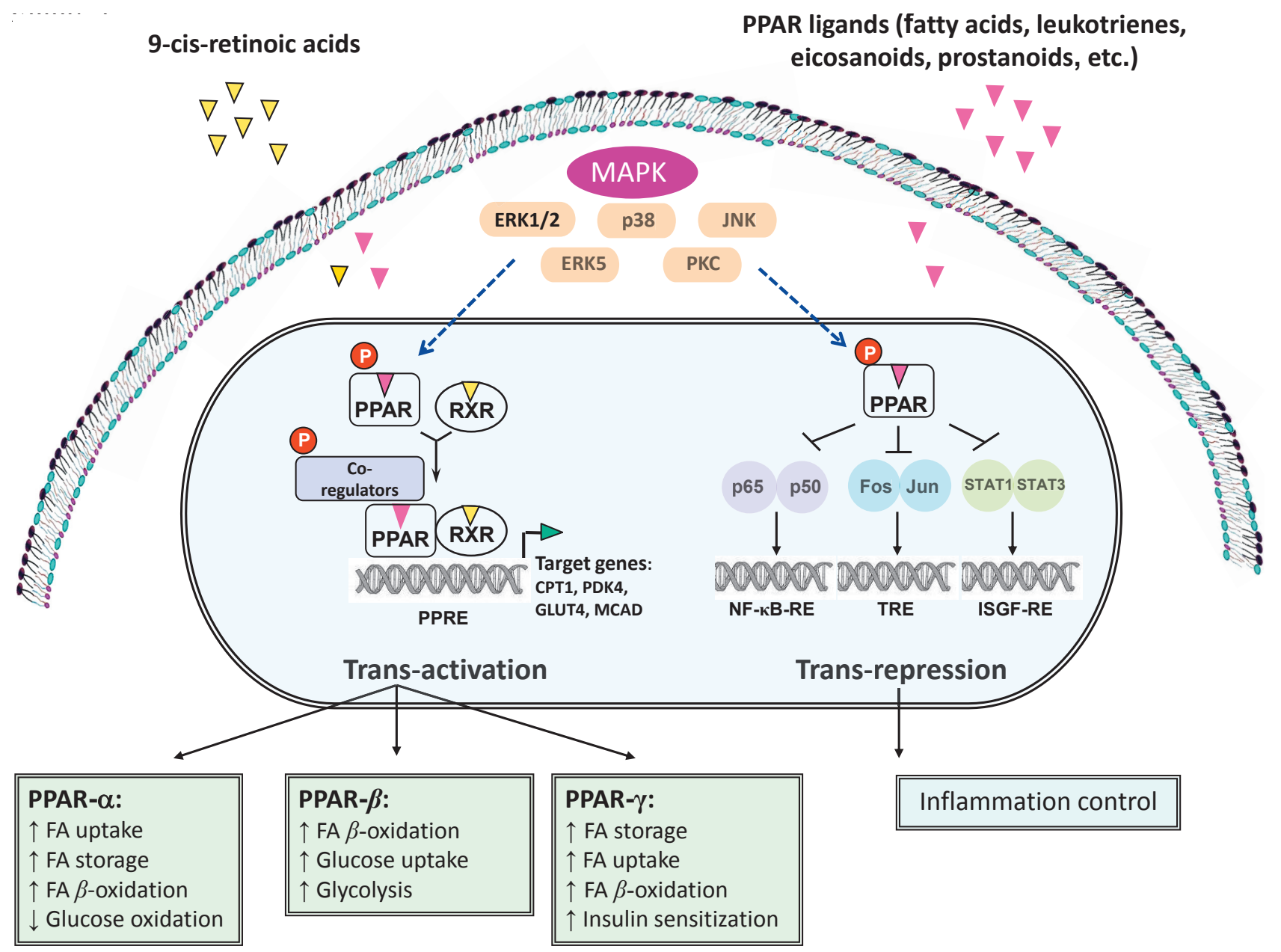

Figure 1. Regulatory pathways of PPARs in the cell and control of gene expression by PPARs. PPARs regulate gene expression by binding with RXR to specific DNA sequence elements (PPRE) located in the promoter region of target genes, thus regulating their transcription and synthesis of the respective gene products (Trans-activation). PPARs repress gene transcription (Trans-repression) by negatively interfering with transcription factors such as NF- $\mathrm{BB}$, STATs, cJun and c-Fos in a DNA-binding independent manner. The activity of PPARs is also regulated by phosphorylation events through MAPK signaling. CPT1, carnitine palmitoyltransferase; ERK, extracellular signal regulated kinases; FA, fatty acids; GLUT4, glucose transporter; ISGF-RE, interferon stimulated gene factor response element; MAPK, mitogen-activated protein kinases; MCAD, medium-chain acyl-CoA dehydrogenase; NF- $\kappa B-R E$, nuclear factor- $\kappa \mathrm{B}$ response element; PDK4, pyruvate dehydrogenase; PPAR, peroxisome proliferator-activated receptors; PPRE, PPAR response element; RXR, retinoid X receptor; STATs, signal transducer and activator of transcription; TRE, TPA (12-O-tetradecanoylphorbol-13-acetate) response element. 


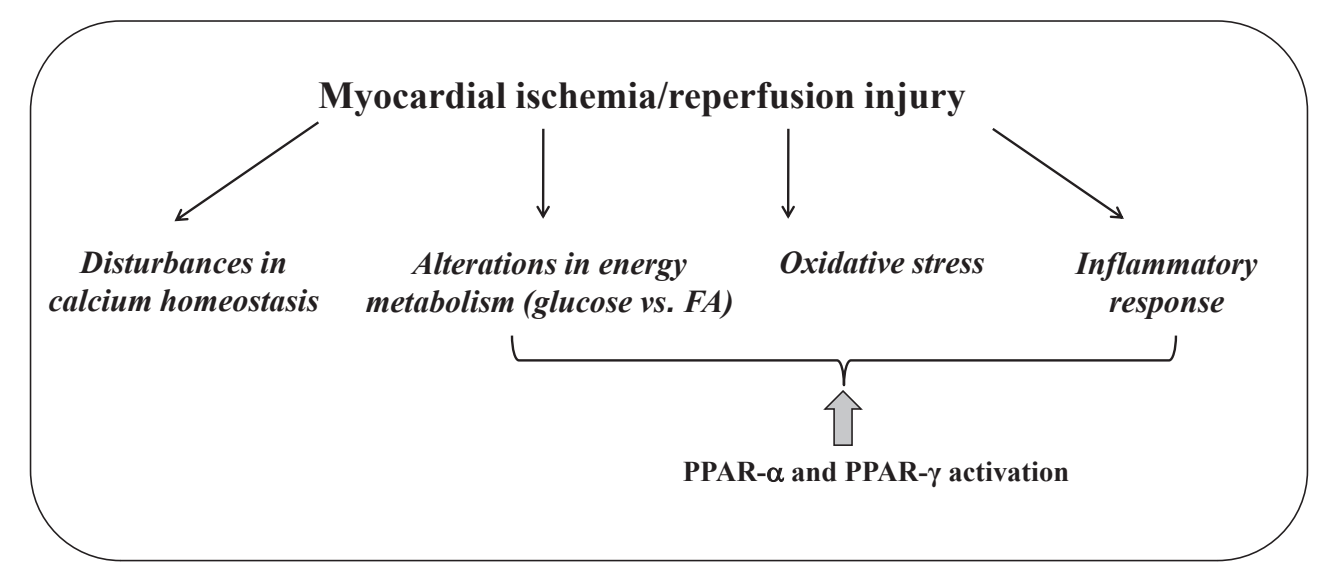

Figure 2. Involvement of PPARs in pathophysiological mechanisms of ischemia/reperfusion injury. FA, fatty acids; PPAR, peroxisome proliferator-activated receptors.

preconditioning against myocardial infarction in rabbits in vivo coupled with an increased transcriptional activity of inducible NO synthase has also been documented (Lotz et al. 2011b).

\section{Cardioprotective effects of exogenous PPAR agonists}

Activation of PPAR- $\alpha$ with synthetic ligands has been shown to be cardioprotective in a setting of I/R as manifested by a reduced infarct size and improved postischemic recovery of contractile function in different in vivo and ex vivo models of I/R (Wayman et al. 2002; Yue et al. 2003; Tian et al. 2006). In this context, treatment with PPAR-a selective and potent agonist GW7647, that reversed I/R-induced down-regulation of PPAR- $\alpha$ and its target genes, attenuated myocardial contractile dysfunction and reduced the size of infarction (Yue et al. 2003). Similar cardioprotective effects, in conjunction with the metabolic effects, were observed in a rat ex vivo model of 30-min ischemia/2-h reperfusion after treatment with PPAR- $\alpha$ agonist clofibrate (Tian et al. 2006). These studies do not support the view of the beneficial role of FAO inhibition in the mechanisms of protection against acute $\mathrm{I} / \mathrm{R}$, at least in this experimental setting.

PPAR- $\alpha$ agonists fibrates have shown protection against myocardial I/R injury beyond their lipid-lowering properties (Wayman et al. 2002). Other potent hypolipidemic drugs, statins, are being also intensively studied in this respect. By inhibition of the enzyme HMG-CoA reductase statins have been reported to prevent the synthesis of isoprenoid intermediates of cholesterol biosynthesis pathway involved in posttranslational modification of small GTP-binding proteins, such as Ras, Rho, and Rac, which modulate a variety of cellular processes (Takemoto and Liao 2001), e.g., oxidative stress and inflammation (Van Linthout et al. 2007; Zhou et al.
2008; Adameová et al. 2009b), vascular endothelial dysfunction (Takemoto and Liao 2001) and the outcome of myocardial response to I/R (Adameová et al. 2006, 2009a). It is hypothesized that in the myocardium, treatment with statins induces preconditioning-like effects attributed to up-regulation of "survival" pathways, such as PI3K/Akt, ERK1/2 and eNOS (Di Napoli et al. 2001; Efthymiou et al. 2005; Merla et al. 2007). In addition, in the hearts of normocholesterolemic rats exposed to I/R after 5-days treatment with simvastatin, a remarkable elevation in PPAR- $\alpha$ gene expression coupled with an enhanced protein expression (3.3-fold and 2-fold increase in mRNA and protein levels, respectively) was observed in the myocardium of these animals at baseline and after 30-min global ischemia and 2 -h reperfusion. This was accompanied by a significant reduction of the infarct size, improved contractile recovery and attenuation of severe ventricular arrhythmias (Ravingerová et al. 2009).

Although statins are not specific PPAR ligands, they have been reported to up-regulate PPAR- $\alpha$ in some cell types, such as human HepG2 hepatoma cells (Martin et al. 2001) or mice peritoneal macrophages (Paumelle et al. 2006) and to increase both PPAR- $\alpha$ expression and its protein levels in primary endothelial cells (Inoue 2000). Our findings provided evidence of the up-regulation of PPAR- $\alpha$ by statins in the myocardium, perhaps not via a direct agonistic mechanism. In support of the view that PPAR- $\alpha$ activation may underlie mechanisms of beneficial effects of statins against lethal myocardial injury in the hearts of normocholesterolemic animals, anti-infarct protection conferred by 5 -days treatment with simvastatin in a rat ex vivo model (Adameová et al. 2009a; Ravingerová et al. 2009) was comparable with the effect of WY14643, a hypolipidemic compound that has been shown to protect rat myocardium against I/R injury (Bulhak et al. 2006) as one of the most potent and selective PPAR- $\alpha$ agonist (Forman et al. 1997). This is also in agree- 
ment with the data documenting a beneficial effect of PPAR$\alpha$ activation on cardiac I/R injury (Wayman et al. 2002; Yue et al. 2003; Tian et al. 2006) indicating that preserved FAO is important for the maintenance of adequate energy production under the conditions of restored coronary flow, when oxygen supply is no longer rate limiting.

\section{PPAR and inflammation}

Protective effects of PPAR agonists may be attributed not only to modulation of cardiac metabolism but also to inhibition of inflammation with the salutatory effects on the cardiac muscle (Diep et al. 2004; Smeets et al. 2007). In fact, in the experiments which have demonstrated beneficial effects of PPAR- $\alpha$ and $-\gamma$ agonists on the myocardial, cerebral and hepatal I/R injury, protection was attributed to the attenuation of oxidative stress and inflammatory response via inhibiton of the activation of NF- $k$ B (Delerive et al. 2000; Yue et al. 2003; Ogata et al. 2004; Collino et al. 2006; Yeh et al. 2006; Xu et al. 2008). Recent study by Collino et al. (2011) has demonstrated protective effects PPAR $\beta / \delta$ agonist against myocardial I/R associated with suppression of proinflammatory cytokines and neutrophil accumulation. Lipophilic HMG-CoA reductase inhibitors exerted an anti-inflammatory effect via reduction of mRNA levels for interleukin-1 $\beta$, interleukin-6, cyclooxygenase-2, and p22phox by up-regulation of PPAR- $\alpha$ (and PPAR- $\gamma$ ) in primary endothelial cells (Inoue et al. 2000). Positive impact of statins on inflammatory processes may be mediated through the activation of both PPAR- $\alpha$ and PPAR- $\gamma$ (Inoue et al. 2002; Zelvyte et al. 2002). Research indicates that acute anti-inflammatory effect of simvastatin occurs through a mechanism involving inhibition of PKC- (and ERK1/2 cascade of MAPK)-induced phosphorylation (and inactivation) of PPAR- $\alpha$, activation of PPAR- $\alpha$ (and PPAR- $\gamma$ ) via a cyclooxygenase (COX)-2-dependent increase in the levels of natural PPAR ligands $15 \mathrm{~d}-\mathrm{PGJ}_{2}$, as well as decreased transactivation of NF- $\kappa \mathrm{B}$ (Inoue et al. 2002; Zelvyte et al. 2002; Paumelle et al. 2006; Yano et al. 2007). Figure 3 summarizes potential mechanisms of PPAR activation as a part of pleiotropic effects of statins induced by the inhibition of HMG-CoA reductase-mevalonate pathway. A remarkable similarity between the pleiotropic effects of statins (including anti-inflammatory and anti-oxidant effects) and the agonists of PPAR-a fibrates, suggests a mechanistic link between these two classes of drugs and similarity in their effects on PPAR-a (Tian et al. 2006; Paumelle and Staels 2008). Thus, an improved outcome of I/R injury in statintreated normocholesterolemic animals may be also linked to anti-inflammatory effects of PPAR activation. In support

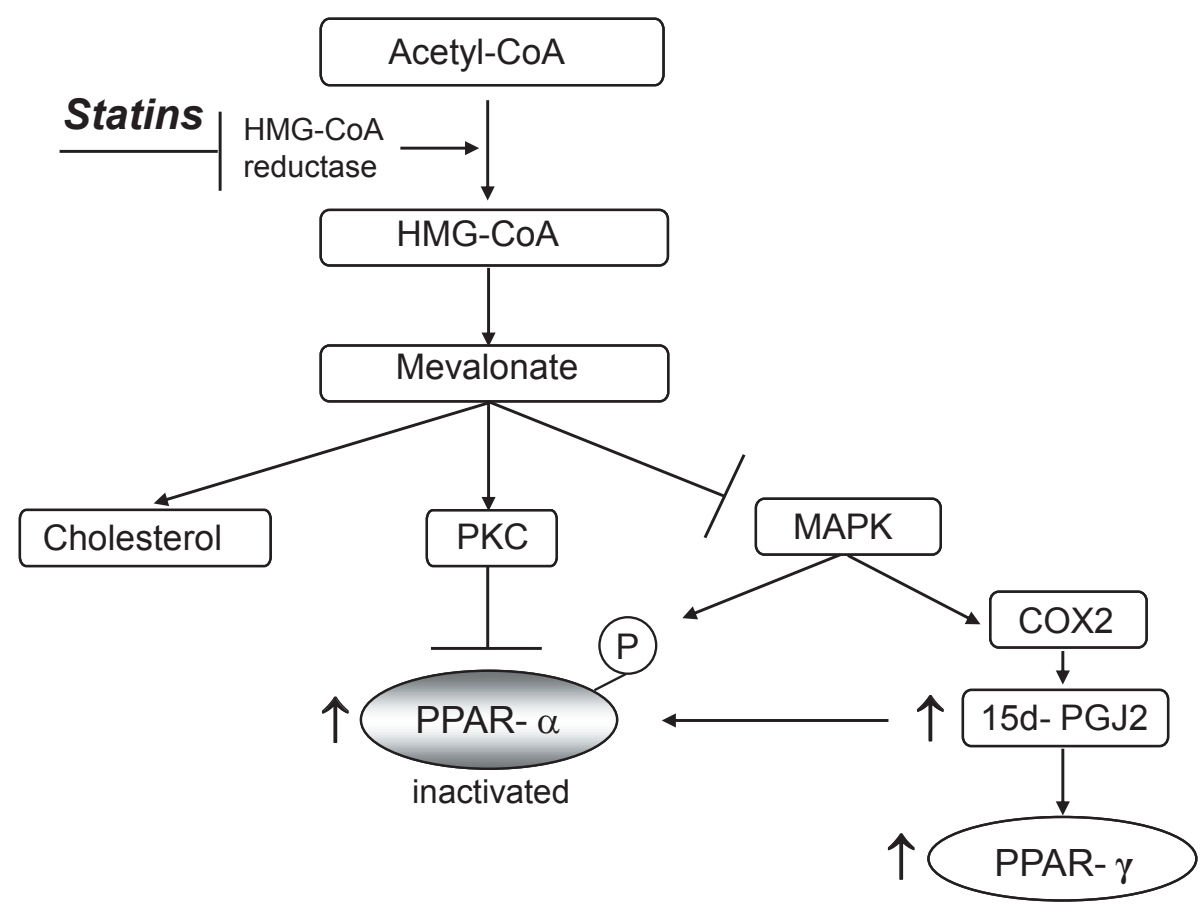

Figure 3. Schematic representation of the potential mechanisms of PPARs activation by statins through the inhibition of HMG-CoA reductase-mevalonate pathway of cholesterol biosynthesis. COX, cyclooxygenase; HMG-CoA, 3-hydroxy-3-methyl-glutaryl-CoA; MAPK, mitogen-activated protein kinases; PGJ2, 15-deoxy-delta-12,14-prostaglandin J2; PKC, protein kinase C; PPAR, peroxisome proliferator-activated receptors. 
of this, Planavila et al. (2005) have reported that atorvastatin treatment prevented both, the fall in the protein levels of PPAR- $\alpha$ and NF- $k$ B activation in pressure overload-induced cardiac hypertrophy.

\section{PPAR function in the diabetic heart: susceptibility to ischemia/reperfusion injury}

PPARs are up-regulated in the diabetic myocardium (Huss and Kelly 2004) that almost exclusively relies on FAO for energy production resulting in higher myocardial oxygen consumption. The latter, along with elevated circulating levels and uptake of FA, as well as excess myocardial lipid accumulation may predispose the heart to contractile dysfunction and failure.

Clinical and epidemiological studies clearly demonstrated that diabetic patients are at a higher risk of congestive heart failure and ischemic heart disease including myocardial infarction and rhythm disorders (Kannel 1985). It has been found that development of diabetes leads to oxidative stress (Singal et al. 2001; Maritim et al. 2003) and defects in the cell sarcolemmal and sarcoplasmic reticular membranes, as well as to alterations in the function of ion transport systems $\left(\mathrm{Na}^{+} / \mathrm{K}^{+}\right.$- and $\mathrm{Ca}^{2+}$-ATPase, $\mathrm{Na}^{+} / \mathrm{H}^{+}$and $\mathrm{Na}^{+} / \mathrm{Ca}^{2+}$ exchangers and $\mathrm{Ca}^{2+}$ channels). The latter leads to abnormal $\mathrm{Na}^{+}$and $\mathrm{Ca}^{2+}$ handling in the diabetic myocardium that might compromise its tolerance to ischemia (Pierce et al. 1990; Lee et al. 1992; Dhalla et al. 1998; Anzawa et al. 2006).

On the other hand, animal studies are not unequivocal and suggest that, besides higher myocardial vulnerability, diabetes mellitus may trigger adaptive processes leading to paradoxically enhanced ischemic tolerance. This is now considered as a form of "metabolic preconditioning" sharing some molecular pathways with endogenous cardioprotection in the non-diabetic heart. In particular, it has been demonstrated that susceptibility to I/R in the experimental model of streptozotocin (STZ)- or alloxan-induced diabetes mellitus is decreased similarly to the effect of preconditioning in the non-diseased animals documented by reduced size of infarction, improved contractile recovery, suppressed arrhythmogenesis and lower myocardial generation of reactive oxygen species during ischemia as compared with non-diabetic hearts (Ravingerová et al. 2003, 2010; Galagudza et al. 2007; Matejíková et al. 2008).

Potential mechanisms of preconditioning-like protection in the diabetic myocardium may involve along with antiapoptotic effects of high glucose itself acting as a preconditioning mimetic in the absence of insulin (Ricci et al. 2008), a higher activity of "survival" protein kinases ERK1/2 and PI3K/Akt in acutely diabetic myocardium (Strnisková et al. 2003; Xu et al. 2004; Tsang et al. 2005; Ma et al. 2006).
In addition, several other protective mechanisms, such as reduction in the levels of pro-inflammatory cytokines, increase in the cell survival factors (HIF1- $\alpha$, VEGF) and angiogenesis, along with reduced fibrosis have been found to be activated in the acute phase of STZ-induced diabetes (Malfitano et al. 2010).

Although PPAR- $\gamma$ agonists, insulin-sensitizing drugs glitazones, are widely used for the control of glycemia in diabetic patients (Grossman and Lessem 1997), the role of PPAR in ischemia-induced myocardial injury in the diabetic myocardium still remains elusive (Nikolaidis and Levine 2004). Limited evidence suggests that increased resistance to ischemia in the experimental models of diabetes mellitus might be coupled with enhanced baseline and post I/R mRNA levels of PPARs in contrast to their marked down-regulation in non-diabetics (Ravingerová et al. 2009, 2010). The latter indicates that the maintenance of enhanced PPAR gene expression during I/R may contribute to improved outcome of myocardial I/R injury in the diabetic heart, at least in the early phase of the disease. Moreover, this protective effect of PPAR up-regulation might possibly involve not only metabolic effects of PPARs but also their anti-inflammatory and antioxidative effects (Delerive et al. 2001; Smeets et al. 2007), through the negative regulation of NF- $\kappa \mathrm{B}$ (Abdelrahman et al. $2005)$, that might be of particular importance in the diabetic myocardium. In line, Khandoudi et al. (2002) have shown that cardioprotective effects of PPAR- $\gamma$ activation in diabetic rat hearts exposed to global $\mathrm{I} / \mathrm{R}$ is associated with inhibition of Jun $\mathrm{NH}(2)$-terminal kinase phosphorylation. Recently, Collino et al. (2011) have demonstrated that acute activation of PPAR- $\beta / \delta$ by its selective agonist GW0742 conferred protection against renal I/R injury in rats with STZ-induced diabetes. Protection of kidney by activated PPAR- $\beta / \delta$ in this model involved attenuation of neutrophil infiltration and decreased proinflammatory cytokine signaling (Collino et al. 2011).

\section{Loss of ischemic tolerance in the diabetic heart}

It has been shown that hypercholesterolemia ( $\mathrm{HCH})$ abrogated cardioprotective effect of preconditioning in the nondiabetic heart via alterations in preconditioning-induced gene expression resulting in an enhanced oxidative/nitrosative stress signaling (Giricz et al. 2006; Kocsis et al. 2010). Similarly, this pathology appeared to be one of the reasons for the loss of enhanced ischemic tolerance in the diabetic rats on 7-day high fat-cholesterol diet (Adameová et al. 2007, 2009a). Thus, comorbidity, such as $\mathrm{HCH}$, blunted infarct size- limiting effect in the Langendorff-perfused hearts and exacerbated severe ventricular arrhythmias in the open-chest in vivo diabetic-hypercholesterolemic animals. Moreover, $\mathrm{HCH}$ suppressed upregulation of myocardial PPAR gene expres- 
sion in diabetics, in particular, it decreased mRNA levels of PPAR- $\gamma$ below those detected in non-diabetic controls both at baseline and after I/R (Ravingerová et al. 2010). In addition, in a similar model of STZ-induced diabetes, inhibition of PPAR- $\beta / \delta$ by its selective antagonist GSK0660 abrogated beneficial effects of PPAR- $\beta / \delta$ activation on renal I/R injury (Collino et al. 2011). These findings indicate that changes in PPAR gene expression might be involved in the adaptive protective mechanisms activated in the diabetic myocardium in the acute phase of the disease to counteract metabolic disorders, while loss of protection might be potentially related to concomitant $\mathrm{HCH}$ and down-regulation of PPAR promoting detrimental pro-inflammatory and oxidative effects.

\section{Summary}

In conclusion, experimental data suggest that changes in gene expression of PPARs are involved in the pathophysiological mechanisms of myocardial injury and may modulate it in a distinct way dependent on the type and duration of cardiac pathology. Collectively, these data indicate that up-regulation of PPARs may underlie mechanisms of preconditioning-like effects observed in the normal animals subjected to different protocols of adaptation prior to sustained ischemia or induced by lipid-independent cardioprotective action of some hypolipidemic drugs in non-diseased myocardium. Likewise, enhanced PPAR activity might be implicated in the mechanisms of enhanced resistance to ischemia in the acute phase of experimental diabetes. Thus, PPARs might represent an important therapeutic target in the management of ischemic heart disease in patients with or without metabolic disorders. However, a more detailed elucidation of the role of PPARs in myocardial ischemic injury and cardioprotection requires further investigation.

Acknowledgements. Supported by grants VEGA SR 2/0054/11, 1/0620/10, APVV-LPP-0393-09, APVV 0538-07 and GSRT 5190/ 2005-759. E.G. and E.B. were recipients of the fellowships provided by the Slovak Academic Information Agency (SAIA).

\section{References}

Abdelrahman M., Sivaraja A., Thiemerman Ch. (2005): Beneficial effects of PPAR-gamma ligands in ischemia-reperfusion injury, inflammation and shock. Cardiovasc. Res. 65, 772-781 http://dx.doi.org/10.1016/j.cardiores.2004.12.008

Adameova A., Kuzelova M., Faberova V., Svec P. (2006): Protective effect of simvastatin and VULM 1457 in ischaemic-reperfused myocardium of the diabetic-hypercholesterolemic rats. Pharmazie 61, 807-808

Adameova A., Kuzelova M., Andelova E., Faberova V., Pancza D., Svec P., Ziegelhöffer A., Ravingerová T. (2007): Hyperc- holesterolemia abrogates an increased resistance of diabetic rat hearts to ischemia-reperfusion injury. Mol. Cell Biochem. 295, 129-136

http://dx.doi.org/10.1007/s11010-006-9282-8

Adameova A., Harcarova A., Matejikova J., Pancza D., Kuzelova M., Carnicka S., Svec P., Bartekova M., Styk J., Ravingerová T. (2009a): Simvastatin alleviates myocardial contractile dysfunction and lethal ischemic injury in rat heart independent of cholesterol-lowering effects. Physiol. Res. 58, 449-454

Adameova A. Xu Y. J., Duhamel T. A., Tappia P. S., Shan L., Dhalla N. S. (2009b): Anti-atherosclerotic molecules targeting oxidative stress and inflammation. Curr. Pharm. Des. 15, 3094-3107 http://dx.doi.org/10.2174/138161209789058048

Anzawa R., Bernard M., Tamareille S., Baetz D., Confort-Gouny S., Gascard J. P., Cozzone P., Feuvray D. (2006): Intracellular sodium increase and susceptibility to ischaemia in hearts from type 2 diabetic $\mathrm{db} / \mathrm{db}$ mice. Diabetologia 49, 598-606 http://dx.doi.org/10.1007/s00125-005-0091-5

Ballantyne C. M., Stein E. A., Paoletti R., Southworth H., Blasetto J. W. (2003): Efficacy of rosuvastatin $10 \mathrm{mg}$ in patients with the metabolic syndrome. Am. J. Cardiol. 91, 25-27C http://dx.doi.org/10.1016/S0002-9149(03)00006-7

Barger P. M., Kelly D. P. (2000): PPAR signaling in the control of cardiac energy metabolism. Trends Cardiovasc. Med. 10, 238-245 http://dx.doi.org/10.1016/S1050-1738(00)00077-3

Barger P. M., Brandt J. M., Leonem T. C., Weinheimer C. J., Kelly D. P. (2000): Deactivation of peroxisome proliferator-activated receptor-alpha during cardiac hypertrophic growth. J. Clin. Invest. 105, 1723-1730 http://dx.doi.org/10.1172/JCI9056

Barger P. M., Browning A. C., Garner A. N., Kelly D. P. (2001): p38 mitogen-activated protein kinase activates peroxisome proliferator-activated receptor alpha: a potential role in the cardiac metabolic stress response. J. Biol. Chem. 276, 44495-444501

http://dx.doi.org/10.1074/jbc.M105945200

Braissant O., Foufelle F., Scotto C., Dauça M., Wahli W. (1996): Differential expression of peroxisome proliferator-activated receptors (PPARs): tissue distribution of PPAR-alpha, -beta, and -gamma in the adult rat. Endocrinology 137, 354-366 http://dx.doi.org/10.1210/en.137.1.354

Braunwald E., Kloner R. A. (1985): Myocardial reperfusion: a double-edged sword? J. Clin. Invest. 76, 1713-1719 http://dx.doi.org/10.1172/JCI112160

Bulhak A. A., Sjöquist P. O., Xu C. B., Edvinsson L., Pernow J. (2006): Protection against myocardial ischaemia/reperfusion injury by PPAR-alpha activation is related to production of nitric oxide and endothelin-1. Basic Res. Cardiol. 101, 244-252 http://dx.doi.org/10.1007/s00395-005-0580-1

Collino M., Patel N. S. A., Lawrence K. M., Collin M., Latchman D. S., Yaqoob M. M., Thiemermann C. (2005): The selective PPAR-gamma antagonist GW9662 reverses the protection of LPS in a model of renal ischemia-reperfusion. Kidney Int. 68, 529-536 http://dx.doi.org/10.1111/j.1523-1755.2005.00430.x

Collino M., Aragno M., Mastrocola R., Benetti E., Gallicchio M., Dianzani C., Danni O., Thiemermann C., Fantozzi R. (2006): Oxidative stress and inflammatory response evoked by tran- 
sient cerebral ischemia/reperfusion: effects of the PPAR-alpha agonist WY14643. Free Radic. Biol. Med. 41, 579-589 http://dx.doi.org/10.1016/j.freeradbiomed.2006.04.030

Collino M., Patel N. S. A., Thiemermann Ch. (2008): PPARs as new therapeutic targets for the treatment of cerebral ischemia/reperfusion. Ther. Adv. Cardiovasc. Dis. 2, 179-197 http://dx.doi.org/10.1177/17539447080909

Collino M., Benetti E., Miglio G., Gastiglia S., Rosa A. C., Aragno M., Thiemermann Ch., Fantozzi R. (2011): Preoxisome proliferatot-activated receptor $\beta / \delta$ agonism protects the kidney against ischemia/reperfusion injury in diabetic rats. Free Radic. Biol. Med. 50, 345-353 http://dx.doi.org/10.1016/j.freeradbiomed.2010.10.710

Delerive P., Fruchart J. C., Staels B. (2001): Peroxisome proliferator-activated receptors in inflammation control. J. Endocrinol. 169, 453-459 http://dx.doi.org/10.1677/joe.0.1690453

Desvergne B., Wahli W. (1999): Peroxisome proliferator-activated receptors: Nuclear control of metabolism. Endocr. Rev. 20, 649-688 http://dx.doi.org/10.1210/er.20.5.649

Dhalla N. S., Liu X., Panagia V., Takeda A. (1998): Subcellular remodeling and heart dysfunction in chronic diabetes. Cardiovasc. Res. 40, 239-247 http://dx.doi.org/10.1016/S0008-6363(98)00186-2

Di Napoli P., Taccardi A. A., Grilli A., Spina R., Felaco M., Barsotti A., De Caterina R. (2001): Simvastatin reduces reperfusion injury by modulating nitric oxide synthase expression: an ex vivo study in isolated working rat hearts. Cardiovasc. Res. 51, 283-293 http://dx.doi.org/10.1016/S0008-6363(01)00306-6

Diep Q. N., Benkirane K., Amiri F., Cohn J. S., Endemann D., Schiffrin E. L. (2004): PPAR alpha activator fenofibrate inhibits myocardial inflammation and fibrosis in angiotensin II-infused rats. J. Mol. Cell. Cardiol. 36, 295-304 http://dx.doi.org/10.1016/j.yjmcc.2003.11.004

Efthymiou C. A., Mocanu M. M., Yellon D. M. (2005): Atorvastatin and myocardial reperfusion injury: new pleiotropic effect implicating multiple prosurvival signaling. J. Cardiovasc. Pharmacol. 45, 247-252 http://dx.doi.org/10.1097/01.fjc.0000154376.82445.06

Escher P., Braissant O., Basu-Modak S., Michalik L., Wahli W., Desvergne B. (2001): Rat PPARs: quantitative analysis in adult rat tissues and regulation in fasting and refeeding. Endocrinology 142, 4195-4202 http://dx.doi.org/10.1210/en.142.10.4195

Feige J. N., Gelman L., Michalik L., Desvergne B., Wahli W. (2006): From molecular action to physiological outputs: peroxisome proliferator-activated receptors are nuclear receptors at the crossroads of key cellular functions. Prog. Lipid Res. 45, 120-159 http://dx.doi.org/10.1016/j.plipres.2005.12.002

Finck B. N. (2007): The PPAR regulatory system in cardiac physiology and disease. Cardiovasc. Res. 73, 269-277 http://dx.doi.org/10.1016/j.cardiores.2006.08.023

Forman B. M., Chen J., Evans R. M. (1997): Hypolipidemic drugs, polyunsaturated fatty acids, and eicosanoids are ligands for peroxisome proliferator-activated receptors alpha and delta. Proc. Natl. Acad. Sci. U.S.A. 94, 4312-4317 http://dx.doi.org/10.1073/pnas.94.9.4312
Fragasso G., Piatti P. M., Monti L., Palloshi A., Setola E., Puccetti P., Calori G., Lopaschuk G. D., Margonato A. (2003): Shortand long-term beneficial effects of trimetazidine in patients with diabetes and ischemic cardiomyopathy. Am. Heart J. 146, E18 http://dx.doi.org/10.1016/S0002-8703(03)00415-0

Galagudza M. M., Nekrasova M. K., Syrenskii A. V., Nifontov E. M. (2007): Resistance of the myocardium to ischemia and the efficacy of ischemic preconditioning in experimental diabetes mellitus. Neurosci. Behav. Physiol. 37, 489-493 http://dx.doi.org/10.1007/s11055-007-0040-5

Gilde A. J., van der Lee K. A., Willemsen P. H., Chinetti G., van der Leij F. R., van der Vusse G. J., Staels B., van Bilsen M. (2003): Peroxisome proliferator-activated receptor (PPAR) alpha and PPARbeta/delta, but not PPARgamma, modulate the expression of genes involved in cardiac lipid metabolism. Circ. Res. 92, 518-524 http://dx.doi.org/10.1161/01.RES.0000060700.55247.7C

Giricz Z., Lalu M. M., Csonka C., Bencsik P., Schulz R., Ferdinandy P. (2006): Hyperlipidemia attenuates the infarct size-limiting effect of ischemic preconditioning: role of matrix metalloproteinase-2 inhibition. J. Pharmacol. Exp. Ther. 316, 154-161 http://dx.doi.org/10.1124/jpet.105.091140

Greene M. E., Blumberg B., McBride O. W., Yi H. F., Kronquist K., Kwan K., Hsieh L., Greene G., Nimer S. D. (1995): Isolation of the human peroxisome proliferator activated receptor gamma cDNA: Expression in hematopoietic cells and chromosomal mapping. Gene Expr. 4, 281-299

Grossman S. L., Lessem J. (1997): Mechanisms and clinical effects of thiazolidinediones. Expert. Opin. Investig. Drugs 6, 1025-1040 http://dx.doi.org/10.1517/13543784.6.8.1025

Hall G., Hasday J. D., Rogers T. B. (2006): Regulating the regulator: NF-kappaB signaling in heart. J. Mol. Cell Cardiol. 41, 580-591 http://dx.doi.org/10.1016/j.yjmcc.2006.07.006

Hausenloy D. J., Tsang A., Mocanu M. M., Yellon D. M. (2005): Ischemic preconditioning protects by activating prosurvival kinases at reperfusion. Am. J. Physiol. Heart Circ. Physiol. 288, H971-976

http://dx.doi.org/10.1152/ajpheart.00374.2004

Huss J. M., Kelly D. P. (2004): Nuclear receptor signaling and cardiac energetics. Circ. Res. 95, 568 http://dx.doi.org/10.1161/01.RES.0000141774.29937.e3

Inoue I., Goto S., Mizotani K., Awata T., Mastunaga T., Kawai S., Nakajima T., Hokari S., Komoda T., Katayama S. (2000): Lipophilic HMG-CoA reductase inhibitor has an anti-inflammatory effect: reduction of MRNA levels for interleukin1beta, interleukin-6, cyclooxygenase-2, and p22phox by regulation of peroxisome proliferator-activated receptor alpha (PPARalpha) in primary endothelial cells. Life Sci. 67, 863-876 http://dx.doi.org/10.1016/S0024-3205(00)00680-9

Inoue I., Itoh F., Aoyagi S., Tazawa S., Kusama H., Akahane M., Mastunaga T., Hayashi K., Awata T., Komoda T., Katayama S. (2002): Fibrate and statin synergistically increase the transcriptional activities of PPARalpha/ RXRalpha and decrease 
the transactivation of NFkappaB. Biochem. Biophys. Res. Commun. 290, 131-139

http://dx.doi.org/10.1006/bbrc.2001.6141

Kannel W. B. (1985): Lipids, diabetes, and coronary heart disease: insights from the Framingham Study. Am. Heart J. 110, $1100-1107$ http://dx.doi.org/10.1016/0002-8703(85)90224-8

Kantor P. F., Lucien A., Kozak R., Lopaschuk G. D. (2000): The antianginal drug trimetazidine shifts cardiac energy metabolism from fatty acid oxidation to glucose oxidation by inhibiting mitochondrial long-chain 3-ketoacyl coenzyme A thiolase. Circ. Res. 86, 580-588

Khandoudi N., Delerive P., Berrebi-Bertrand I., Buckingham R. E., Staels B., Bril A. (2002): Rosiglitazone, a peroxisome proliferator-activated receptor-gamma, inhibits the Jun $\mathrm{NH}(2)$-terminal kinase/activating protein 1 pathway and protects the heart from ischemia/reperfusion injury. Diabetes 51, 1507-1514 http://dx.doi.org/10.2337/diabetes.51.5.1507

Kliewer S. A., Xu H. E., Lambert M. H., Willson T. M. (2001) Peroxisome proliferator-activated receptors: from genes to physiology. Recent Pog. Horm. Res. 56, 239-263 http://dx.doi.org/10.1210/rp.56.1.239

Kliewer S. A., Umesono K., Noonan D. J., Heyman R. A., Evans R. M. (1992): Convergence of 9-cis retinoic acid and peroxisome proliferator signalling pathways through heterodimer formation of their receptors. Nature 358, 771-774 http://dx.doi.org/10.1038/358771a0

Kliewer S. A., Forman B. M., Blumberg B., Ong E. S., Borgmeyer U., Mangelsdorf D. J., Umesono K., Evans R. M. (1994): Differential expression and activation of a family of murine peroxisome proliferator-activated receptors. Proc. Natl. Acad. Sci. U.S.A. 91, 7355-7359 http://dx.doi.org/10.1073/pnas.91.15.7355

Kocsis G. F., Csont T., Varga-Orvos Z., Puskas L. G., Murlasits Z., Ferdinandy P. (2010): Expression of genes related to oxidative/ nitrosative stress in mouse hearts: effect of preconditioning and cholesterol diet. Med. Sci. Monit. 16, BR32-39

Lee S. L., Ostadalova I., Kolar F., Dhalla N. S. (1992): Alterations in $\mathrm{Ca} 2+$-channels during the development of diabetic cardiomyopathy. Mol. Cell. Biochem. 109, 173-179

Lee T. M., Chou T. F. (2003): Troglitazone administration limits infarct size by reduced phosphorylation of canine myocardial connexin 43 proteins. Am. J. Physiol. Heart Circ. Physiol. 285, H1650-1659

Li C., Browder W., Kao R. L. (1999): Early activation of transcription factor NF-kappaB during ischemia in perfused rat heart. Am. J. Physiol. 276, H543-H552

Lotz C., Lange M., Redel A., Stumpner J., Schmidt J., Tischer-Zeitz T., Roewer N., Kehl F. (2011a): Peroxisome-proliferator-activated receptor $\gamma$ mediates the second window of anaestheticinduced preconditioning. Exp. Physiol. 96, 317-324 http://dx.doi.org/10.1113/expphysiol.2010.055590

Lotz C., Lazariotto M., Redel A., Smul T. M., Stumpner J., Blomeyer C., Tischer-Zeitz T., Schmidt J., Pociej J., Roewer N., Kehl F., Lange M. (2011b): Activation of peroxisome-proliferator-activated receptors $\alpha$ and $\gamma$ mediates remote ischemic preconditioning against myocardial infarction in vivo. Exp. Biol. Med. (Maywood) 236, 113-122 http://dx.doi.org/10.1258/ebm.2010.010210

Ma G., Al-Shabrawey M., Johnson J.A., Datar R., Tawfik H. E., Guo D., Caldwell R. B., Caldwell R. W. (2006): Protection against myocardial ischemia/reperfusion injury by short-term diabetes: enhancement of VEGF formation, capillary density, and activation of cell survival signaling. Naunyn. Schmiedebergs. Arch. Pharmacol. 373, 415-427 http://dx.doi.org/10.1007/s00210-006-0102-1

Malfitano C., Alba Loureiro T. C., Rodrigues B., Sirvente R., Salemi V. M., Rabechi N. B., Lacchini S., Curi R., Irigoyen M. C. (2010): Hyperglycaemia protects the heart after myocardial infarction: aspects of programmed cell survival and cell death. Eur. J. Heart Fail. 20, 659-667 http://dx.doi.org/10.1093/eurjhf/hfq053

Maritim A. C., Sanders R. A., Watkins J. B. (2003): Diabetes, oxidative stress, and antioxidants: a review. J. Biol. Mol. Toxicol. 17, 24-38 http://dx.doi.org/10.1002/jbt.10058

Martin G., Duez H., Blanquart Ch., Berezowski V., Poulain P., Fruchart J. C., Najib-Fruchart J., Glineur C., Staels B. (2001): Statin-induced inhibition of the Rho-signaling pathway activates PPARa and induces HDL apoA-I. J. Clin. Invest. 107, $1423-1432$ http://dx.doi.org/10.1172/JCI10852

Matejiková J., Kucharská J., Pancza D., Ravingerová T. (2008): The effect of antioxidant treatment and NOS inhibition on the incidence of ischaemia-induced arrhythmias in the diabetic rat heart. Physiol. Res. 57, S55-60

Merla R., Ye Y., Lin Y., Manickavasagam S., Huang M. H., PerezPolo R. J., Uretsky B. F., Birnbaum Y. (2007): The central role of adenosine in statin-induced ERK1/2, Akt and eNOS phosphorylation. Am. J. Physiol. 293, H1918-1928

Michalik L., Wahli W. (2006): Involvement of PPAR nuclear receptors in tissue injury and wound repair. J. Clin. Invest. 116, 598-606 http://dx.doi.org/10.1172/JCI27958

Nikolaidis L. A., Levine T. B. (2004): Peroxisome proliferator activator receptors (PPAR), insulin resistance, and cardiomyopathy: friends or foes for the diabetic patient with heart failure? Cardiol. Rev. 12, 158-170 http://dx.doi.org/10.1097/01.crd.0000102419.52594.90

Ogata T., Miyauchi T., Sakaiet S., Takanashi M., Irukayama-Tomobe Y., Yamaguchi I. (2004): Myocardial fibrosis and diastolic dysfunction in deoxycorticosterone acetate-salt hypertensive rats is ameliorated by the peroxisome proliferator-activated receptoralpha activator fenofibrate, partly by suppressing inflammatory responses associated with the nuclear factor-kappa-B pathway. J. Am. Coll. Cardiol. 43, 1481-1488 http://dx.doi.org/10.1016/j.jacc.2003.11.043

Oshida Y., Kako M., Nakai N., Shimomura Y., Li L., Sato J., Ohsawa I., Sato Y. (1999): Troglitazone improves insulin-stimulated glucose utilization associated with an increased muscle glycogen content in obese Zucker rats. Endocr. J. 46, 723-730 http://dx.doi.org/10.1507/endocrj.46.723

Panagia M., Gibbons G. F., Radda G. K., Clarke K. (2005): PPARalpha activation required for decreased glucose uptake and increased susceptibility to injury during ischemia. Am. J. Physiol. Heart Circ. Physiol. 288, H2677-2683 http://dx.doi.org/10.1152/ajpheart.00200.2004 
Paumelle R., Blanquart C., Briand O., Barbier O., Duhem C., Woerly G., Percevault F., Fruchart J. C., Dombrowicz D., Glineur C., Staels B. (2006): Acute antiinflammatory properties of statins involve peroxisome proliferator-activated receptor- $\alpha$ via inhibition of the protein kinase C signaling pathway. Circ. Res. 98, 361-369 http://dx.doi.org/10.1161/01.RES.0000202706.70992.95

Paumelle R., Staels B. (2008): Cross-talk between statins and PPARalpha in cardiovascular diseases: clinical evidence and basic mechanisms. Trends Cardiovasc. Med. 18, 73-78 http://dx.doi.org/10.1016/j.tcm.2008.01.001

Pierce G. N., Ramjiawan B., Dhalla N. S., Ferrari R. (1990): Na+/H+ exchange in cardiac sarcolemmal vesicles isolated from diabetic rats. Am. J. Physiol. 258, H255-261

Planavila A., Laguna J. C., Vázquez-Carrera M. (2005): Atorvastatin improves peroxisome proliferator-activated receptor signaling in cardiac hypertrophy by preventing nuclear factor-kappa B activation. Biochim. Biophys. Acta 168, 76-83

Ravingerová T., Neckáŕ J., Koláŕ F. (2003): Ischemic tolerance of rat hearts in acute and chronic phases of experimental diabetes. Mol. Cell. Biochem. 249, 167-174 http://dx.doi.org/10.1023/A:1024751109196

Ravingerová T., Matejíková J., Neckář J., Andelová E., Kolár F. (2007): Differential role of PI3K/Akt pathway in the infarct size limitation and antiarrhythmic protection in the rat heart. Mol. Cell. Biochem. 297, 111-120 http://dx.doi.org/10.1007/s11010-006-9335-z

Ravingerová T., Adameová A., Kelly T., Antonopoulou E., Pancza D., Ondrejcáková M., Khandelwal V. K., Carnická S., Lazou A. (2009): Changes in PPAR gene expression and myocardial tolerance to ischaemia: Relevance to pleiotropic effects of statins. Can. J. Physiol. Pharmacol. 87, 1028-1036 http://dx.doi.org/10.1139/Y09-071

Ravingerová T., Adameová A., Matejíková J., Kelly T., Nemčeková M., Kucharská J., Pecháňová O., Lazou A. (2010): Subcellular mechanisms of adaptation in the diabetic myocardium: relevance to ischemic preconditioning in the non-diseased heart. Exp. Clin. Cardiol. 15, 68-76

Razeghi P., Young, M. E., Abbasi S., Taegtmeyer H. (2001): Hypoxia in vivo decreases peroxisome proliferator-activated receptor alpha-regulated gene expression in rat heart. Biochem. Biophys. Res. Commun. 287, 5-10 http://dx.doi.org/10.1006/bbrc.2001.5541

Ricci C., Jong C. J., Schaffer S. W. (2008): Proapoptotic and antiapoptotic effects of hyperglycemia: role of insulin signaling. Can. J. Physiol. Pharmacol. 86, 166-172 http://dx.doi.org/10.1139/Y08-021

Roberto A., Prado E. A. (2002): Ischemia/reperfusion injury. J. Surg. Res. 105, 248-258 http://dx.doi.org/10.1006/jsre.2002.6385

Rodrígez-Sinovas A., Abdallah Y., Piper H. M., Garcia-Dorado D. (2007): Reperfusion injury as a therapeutic challenge in patients with acute myocardial infarction. Heart Fail. Rev. 12, 207-216 http://dx.doi.org/10.1007/s10741-007-9039-9

Salam N. K., Huang T. H., Kota B. P., Kim M. S., Li Y., Hibbs D. E. (2008): Novel PPAR-gamma agonists identified from a natural product library: a virtual screening, induced-fit docking and biological assay study. Chem. Biol. Drug Des. 71, 57-70 http://dx.doi.org/10.1111/j.1747-0285.2007.00606.x

Sambandam N., Morabito D., Wagg C., Finck B. N., Kelly D. P., Lopaschuk G. D. (2006): Chronic activation of PPARalpha is detrimental to cardiac recovery after ischemia. Am. J. Physiol. Heart Circ. Physiol. 290, H87-95 http://dx.doi.org/10.1152/ajpheart.00285.2005

Shibata H., Spencer T. E., Onate S. A., Jenster G., Tsai S. Y., Tsai M. J., O'Malley B. W. (1997): Role of co-activators and co-repressors in the mechanisms of steroid/thyroid receptor action. Recent Prog. Horm. Res. 52, 141-164

Shiomi T., Tsutsui H., Hayashidani S., Suematsu N., Ikeuchi M., Wen J., Ishibashi M., Kubota T., Egashira K., Takeshita A. (2002): Pioglitazone, a peroxisome proliferator-activated receptor-gamma agonist, attenuates left ventricular remodeling and failure after experimental myocardial infarction. Circulation 106, 3126-3132 http://dx.doi.org/10.1161/01.CIR.0000039346.31538.2C

Sidell R. J., Cole M. A., Draper N. J., Desrois M., Buckingham R. E., Clarke K. (2002): Thiazolidinedione treatment normalizes insulin resistance and ischemic injury in the zucker fatty rat heart. Diabetes 51, 1110-1117 http://dx.doi.org/10.2337/diabetes.51.4.1110

Singal P. K., Bello-Klein A., Farahmand F., Sandhawalia V. (2001): Oxidative stress and functional deficit in diabetic cardiomyopathy. Adv. Exp. Med. Biol. 498, 213-220 http://dx.doi.org/10.1007/978-1-4615-1321-6_27

Sivarajah A., McDonald M. C., Thiemermann C. (2005): The cardioprotective effects of preconditioning with endotoxin, but not ischemia, are abolished by a peroxisome proliferatoractivated receptor-gamma antagonist. J. Pharmacol. Exp. Ther. 313, 896-901 http://dx.doi.org/10.1124/jpet.104.080598

Smeets P. J. H., Planavila A., van der Vusse E., van Bilsen M. (2007): Peroxisome proliferator-activated receptors and inflammation: take it to heart. Acta Physiol. 191, 171-188 http://dx.doi.org/10.1111/j.1748-1716.2007.01752.x

Strnisková M., Barancik M., Neckar J., Ravingerova T. (2003): Mitogen-activated protein kinases in the acute diabetic myocardium. Mol. Cell. Biochem. 249, 59-65 http://dx.doi.org/10.1023/A:1024774303744

Tabernero A., Schoonjans K., Jesel L., Carpusca I., Auwerx J., Andriantsitohaina R. (2002): Activation of the peroxisome proliferator-activated receptor alpha protects against myocardial ischaemic injury and improves endothelial vasodilatation. BMC. Pharmacol. 2, 10 http://dx.doi.org/10.1186/1471-2210-2-10

Takeda K., Ichiki T., Tokunou T., Iino N., Takeshita A. (2001): 15Deoxy-delta 12,14-prostaglandin J2 and thiazolidinediones activate the MEK/ERK pathway through phosphatidylinositol 3-kinase in vascular smooth muscle cells. J. Biol. Chem. 276, 48950-48955 http://dx.doi.org/10.1074/jbc.M108722200

Takemoto M., Liao J. K. (2001): Pleiotropic effects of 3-hydroxy-3methylglutaryl coenzyme a reductase inhibitors. Arterioscler. Thromb. Vasc. Biol. 21, 1712-1719 http://dx.doi.org/10.1161/hq1101.098486

Tan N. S., Michalik L., Desvergne B., Wahli W. (2005): Multiple expression control mechanisms of peroxisome proliferator- 
activated receptors and their target genes. J. Steroid. Biochem. Mol. Biol. 93, 99-105 http://dx.doi.org/10.1016/j.jsbmb.2004.12.025

Tenenbaum A., Motro M., Fisman E. Z., Schwammenthal E., Adler Y., Goldenberg I., Leor J., Boyko V., Mandelzweig L., Behar S. (2004): Peroxisome proliferator-activated receptor ligand bezafibrate for prevention of type 2 diabetes mellitus in patients with coronary artery disease. Circulation 109, 2197-2202 http://dx.doi.org/10.1161/01.CIR.0000126824.12785.B6

Theocharis S., Margeli A., Vielh P., Kouraklis G. (2004): Peroxisome proliferator-activated receptor-gamma ligands as cell-cycle modulators. Cancer Treat. Rev. 30, 545-554 http://dx.doi.org/10.1016/j.ctrv.2004.04.004

Tian Q., Grzemski F. A., Panagiotopoulos S., Ahokas J. T. (2006): Peroxisome proliferator-activated receptor alpha agonist, clofibrate, has profound influence on myocardial fatty acid composition. Chem. Biol. Interact. 160, 241-251 http://dx.doi.org/10.1016/j.cbi.2006.02.003

Tsang A., Hausenloy D. J., Mocanu M. M., Carr R. D., Yellon D. M. (2005): Preconditioning the diabetic heart: the importance of Akt phosphorylation. Diabetes 54, 2360-2364 http://dx.doi.org/10.2337/diabetes.54.8.2360

Turer A. T., Hill J. A. (2010): Pathogenesis of myocardial ischemiareperfusion injury and rationale for therapy. Am. J. Cardiol. 106, 360-368 http://dx.doi.org/10.1016/j.amjcard.2010.03.032

Van Linthout S., Riad A., Dhayat N., Wahli W. (2007): Anti-inflammatory effects of atorvastatin improve left ventricular function in experimental diabetic cardiomyopathy. Diabetologia 50, 1977-1986 http://dx.doi.org/10.1007/s00125-007-0719-8

Wayman N. S., Hattori Y., McDonald M. C., Mota-Filipe H., Cuzzocrea S., Pisano B., Chatterjee P. K., Thiemermann C. (2002): Ligands of the peroxisome proliferator-activated receptors (PPAR-gamma and PPAR-alpha) reduce myocardial infarct size. FASEB J. 16, 1027-1040 http://dx.doi.org/10.1096/fj.01-0793com

Wynne A., Mocanu M., Yellon D. M. (2005): Pioglitazone mimics preconditioning in the isolated perfused rat heart: a role for the prosurvival kinases PI3K and P42/44MAPK. J. Cardiovasc. Pharmacol. 46, 817-822 http://dx.doi.org/10.1097/01.fjc.0000188365.07635.57
Xu G., Takashi E., Kudo M., Ishiwata T., Naito Z. (2004): Contradictory effects of short- and long-term hyperglycemias on ischemic injury of myocardium via intracellular signaling pathway. Exp. Mol. Pathol. 76, 57-65 http://dx.doi.org/10.1016/j.yexmp.2003.08.003

Xu S. Q., Li Y. H., Hu S. H., Chen K., Dong L. Y. (2008): Effects of WY14643 on hepatic ischemia reperfusion injury in rats. World J. Gastroenterol. 14, 6936-6942 http://dx.doi.org/10.3748/wjg.14.6936

Yano M., Matsumura T., Senokuchi T., Ishii N., Murata Y., Taketa K., Motoshima H., Taguchi T., Sonoda K., Kukidome D., Takuwa Y., Kawada T., Brownlee M., Nishikawa T., Araki E. (2007): Statins activate peroxisome proliferator-activated receptor gamma through extracellular signal-regulated kinase $1 / 2$ and p38 mitogen-activated protein kinase-dependent cyclooxygenase- 2 expression in macrophages. Circ. Res. 100, 1442-1451 http://dx.doi.org/10.1161/01.RES.0000268411.49545.9c

Yeh C., Chen T. P., Lee C. H., Ishii N., Murata Y., Taketa K., Motoshima H., Taguchi T., Sonoda K., Kukidome D., Takuwa Y., Kawada T., Brownlee M., Nishikawa T., Araki E. (2006): Cardiomyocytic apoptosis following global cardiac ischemia and reperfusion can be attenuated by peroxisome proliferator-activated receptor alpha but not gamma activators. Shock 26, 262-270 http://dx.doi.org/10.1097/01.shk.0000225863.56714.96

Yue T. L., Bao W., Jucker B. M., Gu J. L., Romanic A. M., Brown P. J., Cui J., Thudium D. T., Boyce R., Burns-Kurtis C. L., Mirabile R. C., Aravindhan K., Ohlstein E. H. (2003): Activation of peroxisome proliferator-activated receptor-alpha protects the heart from ischemia/reperfusion injury. Circulation 108, 2393-2399 http://dx.doi.org/10.1161/01.CIR.0000093187.42015.6C

Zelvyte I., Dominaitiene R., Crisby M., Janciauskiene S. (2002): Modulation of inflammatory mediators and PPARgamma and NFkappaB expression by pravastatin in response to lipoproteins in human monocytes in vitro. Pharmacol. Res. 45, 147-154 http://dx.doi.org/10.1006/phrs.2001.0922

Zhou R., Xu Q., Zheng P., Zheng J., Dai G. (2008): Cardioprotective effect of fluvastatin on isoproterenol-induced myocardial infarction in rat. Eur. J. Pharmacol. 586, 244-250 http://dx.doi.org/10.1016/j.ejphar.2008.02.057

Received: May 18, 2011

Final version accepted: July 11, 2011 